\title{
Penerapan Model Pembelajaran Hellison Untuk Meningkatkan Nilai Tanggung Jawab Siswa Dalam Penggunaan Alat Pembelajaran Penjas
}

\author{
Gilang Ginanjar ${ }^{1}$, Dian Budiana ${ }^{2}$ \\ ${ }^{1}$ Program Studi Pendidikan Guru Sekolah Dasar Pendidikan Jasmani, Universitas Pendidikan Indonesia
}

\begin{tabular}{|c|}
\hline Info Artikel \\
\hline SejarahArtikel: \\
\hline Diterima Januari \\
\hline Disetujui Maret 2018 \\
\hline Dipublikasikan Mei 2018 \\
\hline Keywords: \\
\hline $\begin{array}{l}\text { Model Pembelajaran Hellison, } \\
\text { Nilai Tanggung Jawab, dan Alat } \\
\text { Pembelajaran Penjas }\end{array}$ \\
\hline
\end{tabular}

Nilai Tanggung Jawab, dan Ala

\begin{abstract}
Abstrak
Penelitian ini bertujuan untuk mengetahui apakah model pembelajaran Hellison dapat meningkatkan nilai tanggung jawab siswa dalam penggunaan alat pembelajaran Penjas. Penelitian ini menggunakan metode penelitian tindakan kelas, dengan model penelitian adaptasi dari Elliott. Penelitian dilakukan dalam dua siklus, tiap satu siklus dilaksanakan sebanyak dua kali tindakan penelitian. Subjek penelitian merupakan siswa kelas V 33 orang terdiri dari 17 siswi dan 16 siswa. Teknik pengumpulan data antara lain dengan observasi, catatan lapangan, dan dokumentasi kegiatan pembelajaran selanjutnya data dianalisis menggunakan teknik persentase. Hasil presentase siklus I tindakan I sebesar $43 \%$ siklus II tindakan II sebesar $63 \%$, siklus II tindakan I sebesar $83 \%$ dan siklus II tindakan II sebesar 90\%. Berdasarkan hasil penelitian terhadap nilai tanggung jawab siswa dalam penggunaan alat pembelajaran Penjas telah menunjukkan bahwa model Hellison dapat meningkatkan rasa tanggungjawab siswa.
\end{abstract}

\begin{abstract}
This study aims to determine whether hellison learning model can improve the value of student responsibility in the use of physical education learning tools. This research uses classroom action research with adaptation research model from Elliott. The study was conducted in two cycles, each cycle was carried out twice. The subjects of the study were students of class $V 33$ people consisting of 17 boys and 16 girl. Data collection techniques, among others, with observation, field notes, and documentation of learning activities then data analyzed using percentage techniques. The result of the first cycle percentage of action I was $43 \%$ second cycle II action $63 \%$, cycle II action I was $83 \%$ and second cycle II action was $90 \%$. Based on the results of research on the value of student responsibility in the use of physical education learning tools has shown that the Hellison model can improve student responsibility.
\end{abstract}




\section{PENDAHULUAN}

Sikap tanggung jawab sangat penting untuk kehidupan anak dimasa mendatang. Penanaman rasa tanggung jawab harus dilakukan secara terus menerus, baik di lingkungan rumah maupun sekolah. Salah satu bentuk latihan penanaman rasa tanggung jawab dalam pembelajaran penjas yaitu ketika anak menggunakan dan membereskan alat pembelajaran penjas. Dalam proses pembelajaran yang bertindak sebagai sumber penyampaian pesan tanggung jawab bisa bersumber guru, buku, atau sumber lainnya. Salah satu sumber penyampaian pesan yang dapat digunakan adalah dengan menggunakan media. Media merupakan salah satu peralatan atau perlengkapan pendidikan.

Peralatan (Appartus) adalah sesuatu yang dapat digunakan dan dimanfaatkan oleh siswa untuk melakukan kegiatan/aktivitas diatasnya, dibawahnya, didalam/diantaranya yang relatif mudah untuk dipindah-pindahkan. Perlengkapan pendidikan jasmani artinya segala sesuatu yang dapat digunakan dan dimanfaatkan untuk dilaksanakan, melakukan kegiatan jasmani (Bahagia dan Mudjianto , 2009).

Alat pembelajaran Penjas di SD Negeri Tilil 2 Kota Bandung cukup memadai atau lengkap, namun karena kurangnya memiliki rasa tanggung jawab pribadi pada peserta didik dalam merawat peralatan yang mereka gunakan saat pembelajaran berlangsung. Sehingga, alat yang tersedia menjadi mudah rusak dan bahkan hilang sehingga ketika pembelajaran berikutnya alat-alat Penjas tidak dapat digunakan kembali. Dengan adanya permasalahan tersebut banyak cara yang dapat dilakukan oleh orang tua, guru, pelatih, masyarakat atau orang dewasa untuk mengembangkan rasa tanggung jawab kepada diri setiap individu. Terkait dengan beberapa permasalahan di atas maka penulis tertarik untuk menerapakan suatu model pembelajaran yang dirasa penulis sangat cocok untuk mengatasi permasalahan di atas, yaitu dengan menerapkan model pembelajaran Hellison.

Salah satu model pembelajaran pendidikan jasmani yang termasuk dalam katagori model rekonstruksi social adalah model Hellison (1995), yang berjudul Teaching Responsibility Through Physical Activity dikembangkan oleh Donal R (dalam Widyatmoko, 2014. Hlm. 9). Pembelajaran pendidikan jasmani dalam model ini lebih menekankan pada kesejahteraan individu secara total, pendekatannya lebih berorientasi pada siswa, yaitu self-actualization dan social reconstruction. Model pembelajaran pendidikan jasmani dari Hellison ini diberi nama level of affective development. Tujuan model Hellison ini adalah meningkatkan perkembangan personal dan responsibility siswa dari irresponsibility, self control, involvement, self direction dan caring melalui berbagai aktivitas pengalaman belajar gerak sesuai kurikulum yang berlaku.

Menurut Hellison (1995, dalam Suherman, 2006. hlm. 9). Model Helison ini sering digunakan untuk membina disiplin siswa (selfresponsibility) untuk itu model ini sering digunakan pada sekolah-sekolah yang bermasalah dengan disiplin siswanya. Hellison mempunyai pandangan bahwa: perubahan perasaan, sikap, emosional, dan tanggung jawab sangat mungkin terjadi melalui penjas, namun tidak terjadi dengan sendirinya. Perubahan ini sangat mungkin terjadi manakala penjas direncanakan dan dicontohkan dengan baik dengan mere- 
fleksikan qualitas yang diinginkan. Potensi ini diperkuat oleh keyakinan Hellison bahwa siswa secara alami berkeinginan untuk melakukan sesuatu yang baik dan penghargaan ekstrinsik adalah "counter productive". Melalui model ini guru berharap bahwa siswa berpartisipasi dan menyenangi aktivitas untuk kepentingannya sendiri dan bukannya untuk mendapatkan penghargaan ekstrinsik. Fair play dalam penjas akan direfleksikan dalam kehidupannya seharihari. Oleh karena itu pada dasarnya model Hellison ini dibuat untuk membantu siswa mengerti dan berlatih rasa tanggung jawab pribadi (selfresponsibility) melalui Penjas.

\section{METODE}

Metode yang digunakan dalam penelitian ini adalam metode Penelitian Tindakan Kelas (classroom Action Research). Penelitian tindakan kelas ini merupakan suatu penelitian yang dilakukan didalam kelas, kelas disini dimaksudkan pada suatu tempat adanya interaksi anatara guru dan murid sehingga terjadinya proses belajar mengajar. Desain penelitian yang digunakan dalam penelitian ini adalah desain PTK model John Elliott (dalam Arikunto, 2012, hlm. 16). Adapun tahap-tahapannya sebagai berikut: (1) perencanaan, (2) pelaksanaan, (3) pengamatan (observasi), dan (4) refleksi. Keempat tahap tersebut merupakan suatu putaran yang disebut dengan siklus. Sampel pasa penelitian ini yaitu siswa kelas $\mathrm{V}$ yang berjumlah 33 orang, terdiri dari 17 siswi perempuan dan 16 siswa laki-laki. Sebagaimana dijelaskan Subroto, dkk (2016, hlm. 36) ada tiga variabel yang dikaji dalam penelitian tindakan kelas, yaitu (1) variabel input( siswa kelas V SDN Tilil 2 Kota Bandung); (2) variabel proses (model pembelajaran Hellison); dan (3) variabel output (sikap tanggung jawab). Instrumen yang digunakannya yaitu lembar observasi perilaku tanggung jawab Hellison. Data diolah menggunakan teknik persentase.

\section{HASIL}

Tahapan pelaksanaan tindakan penelitian merupakan aplikasi dari serangkaian perencanaan yang telah disusun untuk mencari solusi dan mengurangi kesulitan siswa melaksanakan pembelajaran yang diberikan guru. Penelitian yang berjudul : Penerapan Model Pembelajaran Hellison untuk Meningkatkan Nilai Tanggung jawab Siswa dalam Penggunaan Alat Pembelajaran Penjas, segala sesuatu yang telah disusun dan dipersiapakan oleh peneliti mulai dari tahapan penyusunan rencana, pelaksanaan tindakan, observasi hingga tahapan refleksi, dapat memberikan jawaban yang positif terhadap permasalahan yang timbul pada siswa serta meningkatkan keberhasilan siswa dalam pembelajaran. Pada bab ini peneliti akan melaporkan hasil penelitian yang dilakukan dengan membahas dan mendeskripsikannya secara bertahap.

Berikut hasil keseluruhan data observasi nilai afektif sikap tanggung jawab pribadi model Hellison dari setiap siswa dari siklus I tindakan I dan tindakan II sampai siklus II tindakan I dan tindakan II diperoleh data presentase peningkatan nilai afektif sikap tanggung jawab siswa model Hellison dari siklus I tindakan I sebesar $43 \%$ siklus II tindakan II sebesar 63\%, siklus II tindakan I sebesar $83 \%$ dan siklus II tindakan II sebesar $90 \%$. 


\section{PEMBAHASAN}

Penerapan model pembelajaran Hellison untuk meningkatkan nilai tanggung jawab siswa dalam penggunaan alat pembelajaran Penjas ini terlihat tercapai dengan adanya sikap yang positif seperti antusias dalam belajar, memiliki kepedulian dengan membantu menyiapkan alat sekaligus membereskan alat pembelajaran, muncul rasa ingin mencoba dan ingin melakukan tugas gerak dengan baik tanpa disuruh dengan penuh semangat ingin mengulang, membantu temannya yang tidak bisa. Menyemangati temannya atau kelompoknya. Hal ini menunjukan hasil yang positif, proses peningkatan ini hasil usaha peneliti dengan selalu meningatkan atau memberikan pengawasan ketika belajar sehingga siswa terpacu untuk terus lebih baik.

Model Hellison dapat memperbaiki rasa tanggung jawab siswa, karena didalamnya terdapat tujuh strategi pembelajaran. sejalan dengan teori Hellison yang kutif Widyatmoko (dalam Zulfa, 2015. hlm. 22) yiatu terdapat tujuh strategi pembelajaran yang sudah digunakan Hellison dalam mengajar tanggung jawab melalui Penjas, yaitu 1) Teacher Talks dan Awarness Talks , 2) Conseling Time, 3) Group Talk, 4) Modelling, 5) Reinformance, 6) Throught Reflection Time, 7) Specifik LevelRelated Strategie.

Strategi teacher talks dan awarness talks memberikan penyedaran setiap tahapan yang akan dilakukan baik secara kognitif maupaun pengalaman, menempatkan siswa, mengarahkan momen-momen penting dalam pembelajaran. Strategi conseling time adalah waktu yang diberikan kepada siswa untuk berkonsultasi apabila ada yang mengalami kesulitan. strategi group talk dimaksudkan untuk membahas segala hal yang berkaitan dengan masalah kelompok dan memberikan kesempatan kepada mereka untuk dapat menentukan tindakan atau solusi yang akan dilakukan dalam kelompoknya. Strategi modelling dimaksudkan memberikan contoh perilaku pada setiap perkembangan. Strategi reinformance adalah proses guru memberikan penguatan pada setiap sikap atau perilaku yang dilakukan siswa yang berhubungan dengan tahapan perkembangan. Strategi throught reflection time adalah waktu yang diberikan kepada siswa untuk memikirkan atau mengevaluasi sikap dan perilaku yang telah dilakukan yang berhubungan dengan tahapan perkembangan tanggung jawabnya. Specifik level-related strategies kegiatan yang dilakukuan untuk meningkatkan interaksi dengan tahapan yang sedang dijalani.

Berikut hasil keseluruhan data presentase nilai afektif sikap tanggung jawab pribadi model Hellison dari setiap siswa dari siklus I tindakan I dan tindakan II sampai siklus II tindakan I dan tindakan II diperoleh data sebagai berikut:

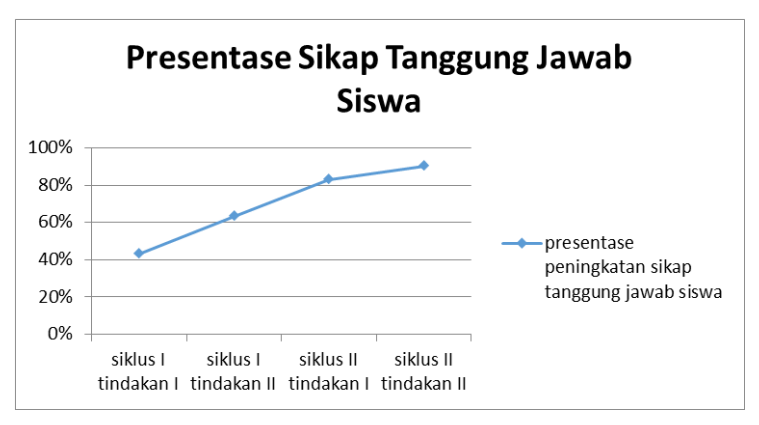

Meningkatnya level perilaku siswa dari tiap tindakan dengan tidak adanya siswa di level perilaku 0 dan 1 , berkurangnya siswa dilevel 2 dengan menaiki level 3 menjadi stabil dan pencapaian yang paling baik bertambahnya sikap tanggung jawab dilevel 4 (Caring). Dengan munculnya atau tumbuhnya sikap tanggung jawab terhadap teman, guru, dan lingkungan 
dari masing-masing siswa tersebut memberikan makna tersendiri bahwa siswa telah mampu melaksanakan sikap tanggung jawab dalam lingkungan pembelajaran Penjas pada level 4 kepedulian (Caring). Hal ini menunjukan proses pembelajaran yang diharapkan tercapai dengan penerapan model pembelajaran Hellison dalam penggunaan alat pembelajaran Penjas efektif dapat meningkatkan rasa tanggung jawab dengan adanya peningkatan dan perkembangan rasa tanggung jawab siswa yang cukup baik dan dapat dikatakan berhasil. Menurut Hellison (dalam Zulfa, 2015, hlm. 17-18) mengemukan bahwa:

Pembelajaran Penjas dalam model Hellison ini lebih menekankan pada kesejahtraan individual total, pendekatannya lebih berorientasi pada siwa, yaitu self-actualization dan social reconstruction. Tujuan model Hellison ini adalah meningkatkan perkembangan personal dan responsibility siswa dari irresponsibility, self control, involvement, self direction dan caring melalui berbagi aktivitas pengalaman belajar gerak sesuai kurikulum yang berlaku. Model Hellison ini sering digunakan untuk membina disiplin siswa (self-responsibility) untuk itu model ini sering digunakan untuk sekolahsekolah yang bermasalah disiplin siswanya.

Perubahan itu dapat terjadi manakala Penjas direncanakan dan dicontohkan dengan merefleksikan kualitas yang diinginkan. Proses pembelajaran yang melibatkan model pembelajaran, suasana yang membuat anak termotivasi, termasuk peralatan yang menunujang aktivitas yang membuat anak merasa senang untuk berpartisipasi penuh dalam pembelajaran. Proses pembelajaran aktivtas jasmani yang terprogram yang berisikan pengembangan karakter yang lebih khusus dengan bidang studi yang lainnya atau proses sosial dapat menumbuhkan kembangkan peserta didik menjadi mahluk sosial yang bermanfaat bagi lingkungan dan dimana pun ia berada.

\section{KESIMPULAN}

Berdasarkan hasil penelitian mengenai Penerapan Model Pembelajaran Hellison untuk Meningkatkan Nilai Tanggung jawab Siswa dalam Penggunaan Alat Pembelajaran Penjas di SD Negeri Tilil 2 Kota Bandung, didapat bahwa model Hellison dapat meningkatkan nilai tanggung jawab siswa dengan adanya peningkatan dan perkembangan nilai tanggung jawab siswa diperoleh data presentase peningkatan nilai afektif sikap tanggung jawab siswa model Hellison dari siklus I tindakan I sebesar 43\% siklus I tindakan II sebesar $63 \%$, siklus II tindakan I sebesar 83\% dan siklus II tindakan II sebesar 90\%. Hal ini ditandai dengan tidak adanya siswa di level perilaku 0 dan 1 , berkurangnya siswa dilevel 2 , stabilnya rasa tanggung jawab siswa pada level 3 (SelfResponsibility) dan menaiki sikap yang paling baik berada dilevel 4 (Caring). 


\section{DAFTAR PUSTAKA}

Arikunto, S dkk. (2012). Penelitian Tindakan Kelas. Jakarta: Bumi Aksara

Bahagia, Y dan Mujianto, S. (2010) Fasilitas dan Perlengkapan Penjas. Bandung.

POR UPI

Hellison, D (1995) Teaching Responsibility Through Physical Activity.

Champaign, IL.: Human Kinetics.

Suherman. (2006). Model Pembelajaran Pendidikan Jasmani. Makalah: FPOK

UPI Bandung.

Sugiyono. (2010). Metode Penelitian Pendidikan Pendekatan Kuantitatif,

Kualitatif, dan R\&D.Bandung: Alfabeta.

Universitas Pendidikan Indonesia. (2015). Pedoman Penulisan Karya Imiah.

Bandung: Universitas Pendidikan Indonesia.

Widiyatmoko, F. (2014). Pengembangan Sikap Bertanggung Jawab Siswa

Melalui Model Hellison dan Canter Assertive. Tesis. Program Pasca Sarjana UPI Bandung.

Zulfa, A. (2015). Implementasi Model Pembelajaran Hellison untuk

Mengembangkan Nilai Tanggung Jawab dalam Pembelajaran Senam (Studi Penelitian Tindakan Kelas di SMP Negeri 45 Bandung). Skripsi. Bandung. Tidak diterbitkan. 